\title{
Batch Crystallization of Active Pharmaceutical Ingredient: Kinetics and Equilibrium Modelling
}

\author{
M. Trampuž, ${ }^{*}$ D. Teslić, ${ }^{b}$ and B. Likozara
}

a Department of Catalysis and Chemical Reaction Engineering, National Institute of Chemistry,

Hajdrihova 19, 1001 Ljubljana, Slovenia

b Sandoz Development Centre Slovenia, Lek d.d., Kolodvorska 27, 1234 Mengeš, Slovenia

\begin{abstract}
Development of a mathematical model for batch crystallization of fesoterodine fumarate, an active pharmaceutical ingredient, in 2-butanone is presented. The model is based on population, mass and energy balances, and takes into account nucleation, crystal growth and agglomeration. Equilibrium solubility was determined experimentally by ATR-FTIR spectroscopy. Kinetic parameters were determined by fitting of experimental and simulated concentration curves and particle size distributions for six crystallization experiments, performed under different operating conditions. The model was validated and the results show good agreement with experimental data.
\end{abstract}

\section{Keywords}

Pharmaceutical, crystallization, modelling, kinetics, equilibrium, fesoterodine fumarate

\section{Introduction}

Crystallization is the most important separation and purification operation in the pharmaceutical industry for the production of chemical intermediates and active pharmaceutical ingredients (APIs). The majority of crystallizations in pharmaceutical industry are batch crystallizations from solutions, where supersaturation is achieved either by cooling and/or addition of an antisolvent. The operating conditions of a crystallization process determine the physicochemical properties of the solid crystal product, such as particle size distribution, polymorphic form, crystal morphology and purity. These can have a profound impact on downstream processing and most importantly on stability and therapeutic properties of the final formulation. In order to ensure safety and efficacy of pharmaceuticals, the regulatory agencies have set strict standards, which include control and consistency of solid phase properties through crystallization. This requires in-depth understanding of the fundamental crystallization phenomena (nucleation, crystal growth, agglomeration etc.), as well as the impact of crystallization equipment and the critical issue of scale-up. Mathematical modelling has been acknowledged as a valuable tool for design, optimization and control of crystallization processes. However, due to the complexity of the process, crystallization modelling has not yet been generalized to the degree that has been accomplished for other unit operations. ${ }^{1-3}$

Fesoterodine fumarate is a muscarinic receptor antagonist that is used for the treatment of overactive bladder syndrome. It exists in several polymorphic forms (I, A, B, C), but it is possible to obtain pure form I crystals by cooling crystallization using 2-butanone as the solvent. ${ }^{4}$ According to the best of our knowledge, the solubility data, mechanism and kinetics of fesoterodine fumarate formation by crystallization have not yet been described in scientific literature.

The purpose of our work was to determine the thermodynamic and kinetic parameters of fesoterodine fumarate cooling crystallization in 2-butanone. A mathematical model of the process was developed, which was supported by experimental determination of solubility equilibrium using calibrated Attenuated total reflectance Fourier-transform infrared (ATR-FTIR) spectroscopy and six crystallization experiments, performed under five different operating conditions. The model was validated by a comparison of the simulated results with experimental results performed under different operating conditions.

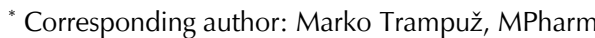
email: marko.trampuz@ki.si
} 


\section{Experimental}

\subsection{Materials and methods}

Fesoterodine fumarate and 2-butanone were donated from Lek d. d. All experiments were performed in 2-L batch reactor AP01-2 with pitched blade turbine impeller (4 blades), integrated into a RC1e reactor system (Mettler Toledo, Switzerland) with DW Therm silicone oil (DWS Dr. Wilharm Synthesetechnik, Germany) as the cooling medium in the jacket. Solution concentration measurements were performed using in-line ATR-FTIR spectroscopy ReactIR 45m (Mettler Toledo) with SiComp ${ }^{\mathrm{TM}}$ sensor and fibre probe. Infrared spectra were recorded between 2800 and $650 \mathrm{~cm}^{-1}$ with resolution of $4 \mathrm{~cm}^{-1}$ and averaged over 128 scans. iC IR 7.0 software (Mettler Toledo) was used for ReactIR $45 \mathrm{~m}$ calibration and solution concentration calculation. Particle size distributions of final crystalline products were determined by optical microscope Olympus BX51 (Olympus, Japan) coupled with Stream Motion image analysis software (Olympus). Mathematical modelling was performed in Matlab (Mathworks, MA, USA).

\subsection{Mathematical model}

Crystallization process may be described by three timedependent balances: population, energy and mass balances. Population balance equation is a partial integrodifferential equation that describes the evolution of crystal size distribution during the process. If numerically solved by Abbas discretization technique, ${ }^{5}$ it can be written for $r$ size classes as a system of ordinary differential equations (Eq. (1) for $i=1$, Eq. (2) for $i=2, \ldots, r-1$ and Eq. (3) for $i=r)$.

$$
\begin{gathered}
\frac{\mathrm{d} N_{1}}{\mathrm{~d} t}=B_{\mathrm{N}}-\mathrm{G}_{1}\left(\frac{N_{1}}{2 W_{1}}\right)+R_{1} \\
\frac{\mathrm{d} N_{\mathrm{i}}}{\mathrm{d} t}=\mathrm{G}_{\mathrm{i}-1}\left(\frac{N_{\mathrm{i}-1}}{2 W_{\mathrm{i}-1}}\right)-\mathrm{G}_{\mathrm{i}}\left(\frac{N_{\mathrm{i}}}{2 W_{\mathrm{i}}}\right)+R_{\mathrm{i}} \\
\frac{\mathrm{d} N_{\mathrm{r}}}{\mathrm{d} t}=\mathrm{G}_{\mathrm{r}-1}\left(\frac{N_{\mathrm{r}-1}}{2 W_{\mathrm{r}-1}}\right)+R_{\mathrm{r}}
\end{gathered}
$$

$N_{i}$ represents number of crystals in class $i[-], B_{N}$ nucleation rate $\left[1 \mathrm{~s}^{-1}\right], G_{i}$ linear crystal growth rate in class $i\left[\mathrm{~m} \mathrm{~s}^{-1}\right], w_{i}$ size class width for class $i[\mathrm{~m}]$, and $R_{i}$ crystal agglomeration rate in class $i\left[1 \mathrm{~s}^{-1}\right]$.

Nucleation (Eq. (4)) takes place in the smallest size class. Only secondary nucleation was taken into account.

$$
B_{\mathrm{N}}=k_{\mathrm{N}} m_{\mathrm{cr}} V_{\mathrm{sol}}\left(C-C_{\mathrm{s}}\right)^{n}
$$

$k_{\mathrm{N}}$ is nucleation rate constant $\left[1 \mathrm{~m}^{-3} \mathrm{~kg}^{-1} \mathrm{~s}^{-1}\right], m_{\mathrm{cr}}$ total mass of crystals [kg], $V_{\text {sol }}$ solution volume $\left[\mathrm{m}^{3}\right], \mathrm{C}$ bulk solution concentration $\left[\mathrm{kg} \mathrm{kg}^{-1}\right.$ of solvent], $C_{S}$ saturated solution concentration [ $\mathrm{kg} \mathrm{kg}^{-1}$ of solvent], and $n$ nucleation order $[-]$.

Crystal growth (Eq. (5)) can be perceived as a two-step mechanism with mass transfer from bulk solution to solidliquid interface and solute integration from the interface into the crystal lattice. No crystal growth takes place from the largest size class $r$. A quantitative measure of mass transfer from the bulk solution to the interface is solidliquid mass transfer coefficient $k_{\mathrm{d}, \mathrm{i}}\left[\mathrm{m} \mathrm{s}^{-1}\right]$. It can be calculated by Frossling equation (Eq. (6)).

$$
\begin{gathered}
G_{\mathrm{i}}=\frac{k_{\mathrm{a}} k_{\mathrm{d}, \mathrm{i}} \rho_{\mathrm{sol}}}{3 \rho_{\mathrm{cr}} k_{\mathrm{v}}}\left(C-C_{\mathrm{m}, \mathrm{i}}\right)=\frac{k_{\mathrm{a}} k_{\mathrm{G}} \rho_{\mathrm{sol}}}{3 \rho_{\mathrm{cr}} k_{\mathrm{v}}}\left(C_{\mathrm{m}, \mathrm{i}}-C_{\mathrm{S}}\right)^{\mathrm{g}} \\
k_{\mathrm{d}, \mathrm{i}}=\frac{D}{L_{\mathrm{i}}}\left(2+1.10 \operatorname{Re}_{\mathrm{p}, \mathrm{i}}^{1 / 2} S C^{1 / 3}\right)
\end{gathered}
$$

$k_{\mathrm{a}}$ and $k_{\mathrm{v}}$ represent crystal area and volume factors [-], $\rho_{\mathrm{sol}}$ is solution density $\left[\mathrm{kg} \mathrm{m}^{-3}\right], \rho_{\mathrm{cr}}$ crystal density $\left[\mathrm{kg} \mathrm{m}^{-3}\right], C_{\mathrm{m}, i}$ interfacial solution concentration for class $i\left[\mathrm{~kg} \mathrm{~kg}^{-1}\right.$ of solvent], $k_{\mathrm{G}}$ crystal growth rate constant $\left[\mathrm{m} \mathrm{s}^{-1}\right], g$ crystal growth order $[-], D$ diffusion coefficient $\left[\mathrm{m}^{2} \mathrm{~s}^{-1}\right], L_{i}$ crystal size on the boundary between classes $i$ and $I+1[\mathrm{~m}], \operatorname{Re}_{\mathrm{p}, i}$ Reynolds number of crystals in class $i[-]$, and Sc Schmidt number [-].

Agglomeration of crystals of classes $j$ and $k(k \geq j)$ into crystals of class I can be described by Eq. (7) using the approach of Marchal. ${ }^{6}$ Crystals from the largest size class $i=r$ do not agglomerate, however, they may be formed by agglomeration of smaller crystals. Laminar collision was assumed as the agglomeration mechanism.

$R_{\mathrm{i}}=\sum_{m=1}^{m_{\max }} k_{\mathrm{R}} G_{l}\left(S_{\mathrm{j}}+S_{\mathrm{k}}\right)^{3}\left(\frac{p}{v}\right)^{1 / 2} N_{\mathrm{j}} N_{\mathrm{k}}\left(\frac{S_{\mathrm{j}}^{3}+S_{\mathrm{k}}^{3}}{S_{1}^{3}} \delta_{\mathrm{i}, 1}-\left(\delta_{\mathrm{i}, \mathrm{j}}+\delta_{\mathrm{i}, \mathrm{j}}\right)\right)$

where $m$ is agglomeration index $[-], k_{R}$ crystal agglomeration rate constant $\left[\mathrm{s} \mathrm{m}^{-7}\right], S_{i}$ average size of crystals in class $i[\mathrm{~m}], P$ dissipated power per unit mass $\left[\mathrm{W} \mathrm{kg}^{-1}\right], v$ kinematic viscosity $\left[\mathrm{m} \mathrm{s}^{-2}\right]$, and $\delta_{\mathrm{i}, \mathrm{j}}$ Kronecker delta [-].

Temperature change in the reactor during the crystallization process is described by Eq. (8). The enthalpy of crystallization was neglected. Total heat transfer coefficient $U\left[\mathrm{~W} \mathrm{~m}^{-2} \mathrm{~K}^{-1}\right]$ is calculated by Eq. (9). Reactorside and jacket-side convective heat transfer coefficients $h_{\mathrm{r}}$ and $h_{\mathrm{j}}\left[\mathrm{W} \mathrm{m}{ }^{-2} \mathrm{~K}^{-1}\right]$ are determined by standard correlations for stirred jacketed reactor.

$$
\frac{\mathrm{d} T_{\mathrm{r}}}{\mathrm{d} t}=\frac{U A\left(T_{\mathrm{j}}-T_{\mathrm{r}}\right)}{m_{\mathrm{r}} C_{\mathrm{p}, \mathrm{r}}}
$$




$$
\frac{1}{U}=\frac{1}{h_{r}}+\frac{x}{\lambda_{w}}+\frac{1}{h_{j}}
$$

$T_{\mathrm{r}}$ and $T_{\mathrm{j}}$ represent reactor and jacket temperatures $\left[{ }^{\circ} \mathrm{C}\right], A$ area of reactor wall available for heat transfer $\left[\mathrm{m}^{2}\right], m_{\mathrm{r}}$ total mass of crystallization mixture $[\mathrm{kg}], c_{\mathrm{p}, \mathrm{r}}$ specific heat capacity of crystallization mixture $\left[\mathrm{kg}^{-1} \mathrm{~K}^{-1}\right], x$ reactor wall width $[\mathrm{m}]$, and $\lambda_{w}$ reactor wall thermal conductivity [W $\left.\mathrm{mK}^{-1}\right]$.
Bulk solution concentration at a certain time $t$ during the process is calculated by subtracting the mass of the formed crystals $m_{\mathrm{cr}}$ at that time from the mass of initially dissolved solute $m_{0}[\mathrm{~kg}]$ and mass of added seed crystals $m_{\text {seed }}[\mathrm{kg}]$, divided by mass of solvent $m_{\text {sol }}[\mathrm{kg}]$ (Eq. (10)). Total mass of the crystals is calculated as the sum of masses of crystals within individual classes (Eq. (11)).

$$
\begin{aligned}
& C(t)=\frac{m_{0}+m_{\text {seed }}-m_{\mathrm{cr}}(t)}{m_{\text {sol }}} \\
& m_{\mathrm{cr}}(\mathrm{t})=k_{\mathrm{v}} \rho_{\mathrm{cr}} \sum_{\mathrm{i}=1}^{\mathrm{r}} N_{\mathrm{i}}\left((t) S_{\mathrm{i}}^{3}\right.
\end{aligned}
$$

Table 1 - List of crystallization experiments with corresponding operating conditions. $d_{50}$ is number-based crystal size distribution median.

Tablica 1 - Popis eksperimenata kristalizacije s odgovarajućim radnim uvjetima. $d_{50}$ je brojčani medijan raspodjele veličine kristala.

\begin{tabular}{c|c|c|c|c|c}
\hline $\begin{array}{c}\text { Experiment/ } \\
\text { Eksperiment }\end{array}$ & $\begin{array}{c}\text { Cooling rate } \\
\text { Brzina hlađenja } \\
/{ }^{\circ} \mathrm{Ch}^{-1}\end{array}$ & $\begin{array}{c}\text { Seed d50 } \\
\text { Cjepivo d50 } \\
/ \mu \mathrm{m}\end{array}$ & $\begin{array}{c}\text { Amount of seed } \\
\text { Količina cjepiva } \\
/ \text { weight } \%\end{array}$ & $\begin{array}{c}\text { Seeding } \\
\text { temperature } \\
\text { Temperatura } \\
\text { cijepljenja } \\
/{ }^{\circ} \mathrm{C}\end{array}$ & $\begin{array}{c}\text { Stirring rate } \\
\text { Brzina miješanja } \\
/ \mathrm{min}^{-1}\end{array}$ \\
\hline 1 & 2.5 & 3.7 & 5.0 & 35.0 & 300 \\
2 & 2.5 & 3.7 & 10.0 & 35.0 & 300 \\
3 & 2.5 & 5.8 & 5.0 & 35.0 & 300 \\
5 & 2.5 & 5.8 & 5.0 & 35.0 & 400 \\
7 & 2.5 & 5.8 & 5.0 & 30.0 & 300 \\
\hline
\end{tabular}

\subsection{ATR-FTIR calibration}

ATR-FTIR spectroscopy was calibrated with solutions between 0.012 and $0.199 \mathrm{~kg} \mathrm{~kg}^{-1}$ of solvent at temperatures from -10.0 to $40.0^{\circ} \mathrm{C}$ (43 combinations). Ten spectra were recorded for every combination of temperature and concentration, with seven spectra used for calibration and three spectra for validation. A multivariate calibration model was constructed between concentration as dependent variable and spectral data and solution temperature as independent variables using partial least squares (PLS) regression. All spectral data at wavenumbers between 660 and $1850 \mathrm{~cm}^{-1}$ were used, which means 319 variables were taken into account for every spectra (altogether 320 independent variables including temperature). Models with different number of latent factors were evaluated and the one with 5 latent factors was chosen as it gave an excellent fit $\left(R^{2}\right.$ and $Q^{2}$ both above 0.99) with the smallest number of factors used.

\subsection{Equilibrium determination}

Equilibrium (saturated) concentration was determined isothermally at different temperatures from -10.0 to $40.0^{\circ} \mathrm{C}$. An excess of fesoterodine fumarate was suspended in 2-butanone at $40^{\circ} \mathrm{C}$ and stirred at $300 \mathrm{rpm}$ for $7 \mathrm{~h}$. Temperature was decreased in step of $5.0^{\circ} \mathrm{C}$ and stirred for 7 h every step.

\subsection{Crystallization experiments}

Six cooling crystallization experiments were conducted for determination of kinetic parameters under different operating conditions (Table 1; Exp. 1-6) and one experiment was conducted for model validation (Exp. 7). Fesoterodine fumarate $(0.100 \mathrm{~kg})$ was dissolved in $0.482 \mathrm{~kg}$ of 2-butanone $\left(0.207 \mathrm{~kg} \mathrm{~kg}^{-1}\right.$ of solvent $)$ at $40.0{ }^{\circ} \mathrm{C}$ and the mixture was linearly cooled to $-10.0^{\circ} \mathrm{C}$. Solution concentration during crystallization was measured by ATR-FTIR spectroscopy. Seed crystals were added at the specified temperature. The following process conditions 
were varied: cooling rate, size of seed, amount of seed, seeding temperature and stirring rate. When the final temperature was reached, the suspension was stirred for additional $30 \mathrm{~min}$. The white solid was filtered and dried for $20 \mathrm{~h}$ at $30^{\circ} \mathrm{C}$ in vacuo.

\subsection{Kinetic parameter determination}

Matlab function fminsearch, based on Nelder-Mead simplex method, was used for determination of kinetic parameters $k_{\mathrm{N}}, n, k_{\mathrm{G}}, g$, and $k_{\mathrm{R}}$ through nonlinear regression of experimental and simulated concentration curves and crystal size distributions.

\section{Results and discussion}

Equilibrium solubility of fesoterodine fumarate in 2 -butanone in the studied temperature range is shown in Fig. 1. For modelling purposes, a $6^{\text {th }}$ degree polynomial was fitted to the experimentally determined data. The solubility curve can be represented by Eq. (12).

$$
\begin{gathered}
C_{s}=1.61 \cdot 10^{-10} T^{6}-7.12 \cdot 10^{-9} T^{5}+1.02 \cdot 10^{-7} T^{4}+ \\
+8.07 \cdot 10^{-7} T^{3}+3.02 \cdot 10^{-6} T^{2}+4.76 \cdot 10^{-4} T+0.0258
\end{gathered}
$$

Experimentally determined concentration curves show that no crystallization occurs prior to seed addition (Fig. 2; left). A few degrees below seeding, a profound drop in concentration to equilibrium solubility is observed, which is fastest in Exp. 2, where the largest amount of seed was added, and slowest in Exp. 6, where the highest cooling rate was used. Final size of particles ranges between approximately 1 and $50 \mu \mathrm{m}$ for all six experiments (Fig. 2; right).

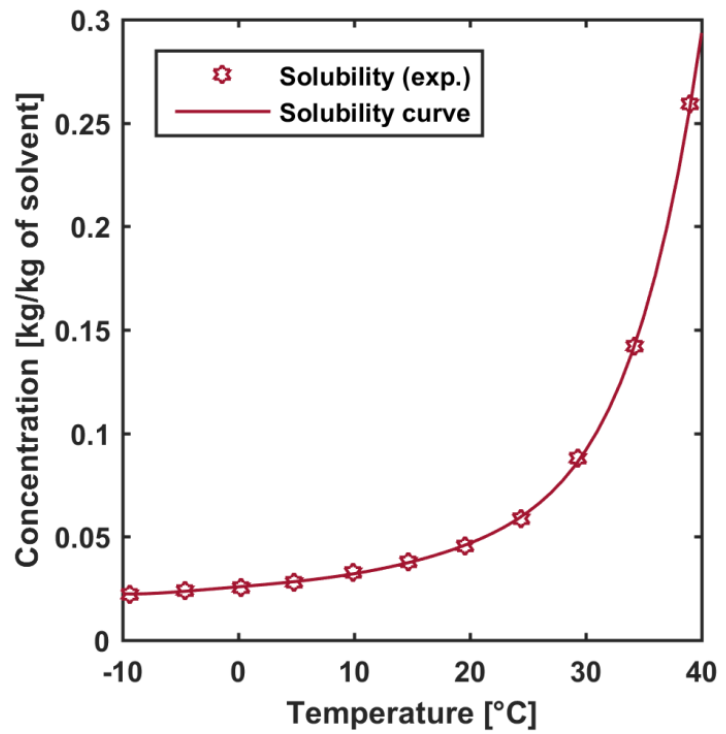

Fig. 1 - Equilibrium solubility of fesoterodine fumarate in 2butanone

Slika 1 - Ravnotežna topljivost fezoterodin fumarata u 2-butanonu
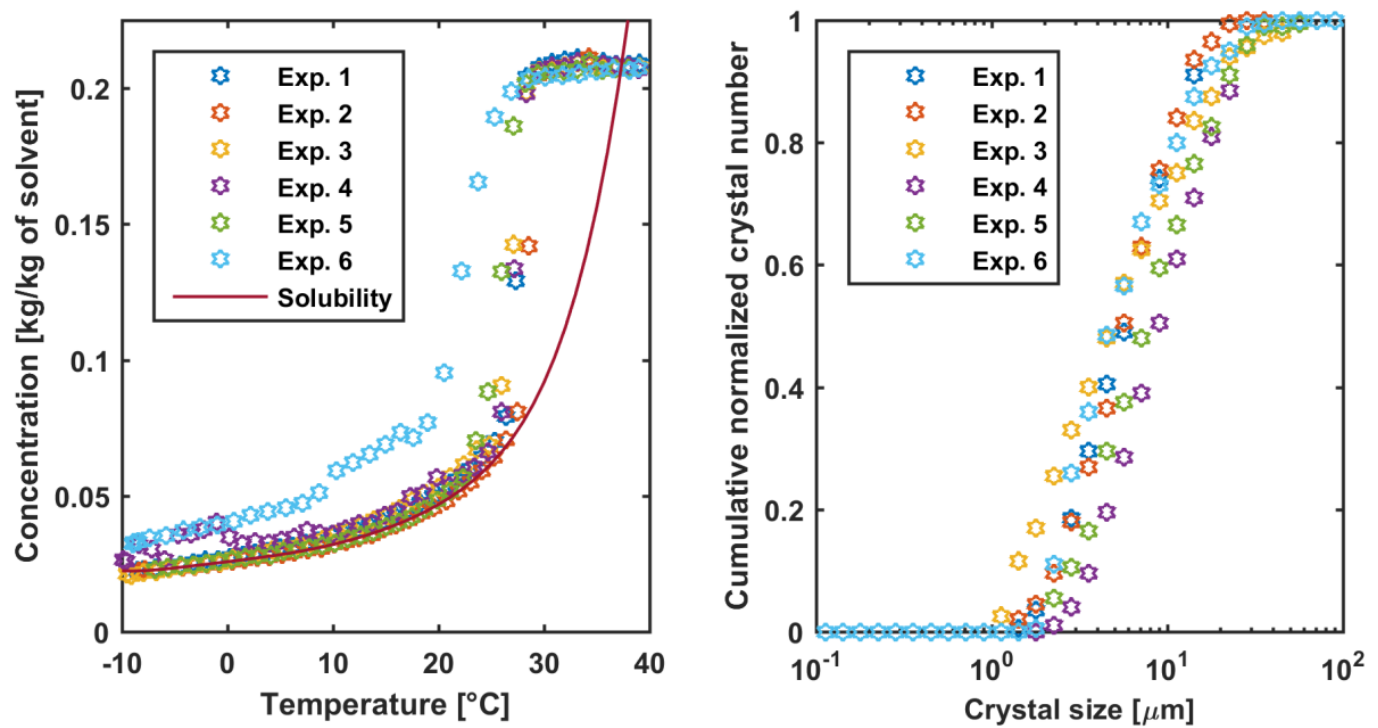

Fig. 2 - Experimental concentration curves and particle size distributions for Exp. 1-6

Slika 2 - Eksperimentalne krivulje koncentracije i raspodjele veličine čestica za Exp. 1-6 

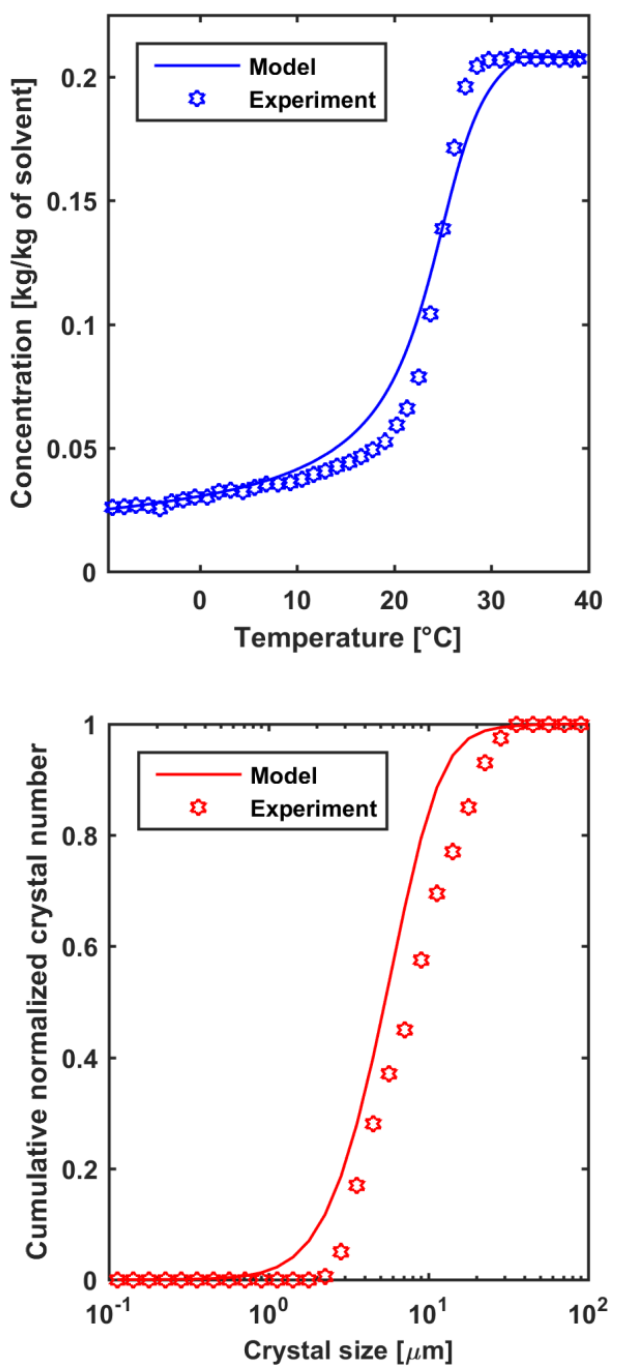

Fig. 3 - Validation of particle size distribution and concentration curve prediction

Slika 3 - Validacija predviđanja raspodjele veličine čestica i krivulje koncentracije
The amount of seed has no profound impact on the final particle size distribution, indicating that nucleation and agglomeration play an important role in the process. However, initial particle size distribution of added seed does impact the final product, as larger particles are obtained by using seed crystals of larger average size. Lower seeding temperature leads to formation of smaller crystals due to higher nucleation rate, while higher stirring rate leads to larger crystals of the product due to higher rate of crystal growth and agglomeration. Higher cooling rate leads to formation of smaller particles as higher supersaturation and thus nucleation rate is achieved. Optimized kinetic parameters of nucleation, crystal growth and crystal agglomeration are listed in Table 2. Orders of nucleation and crystal growth are larger than 1, indicating nonlinear dependence of respective rates on supersaturation.

Nucleation order is larger than crystal growth order, which means that, at lower supersaturations, only crystal growth takes place. Value of crystal growth constant is lower than the calculated value of mass transfer coefficient $\left(10^{-2}-10^{-5} \mathrm{~m} \mathrm{~s}^{-1}\right.$, depending on particle size), indicating that integration is the rate-limiting step.

The results of model validation are shown in Fig. 3, where a good agreement between predicted and experimental results is achieved. The model predicts slightly higher initial crystal growth rate, which can be seen as faster concentration decrease after seeding (Fig. 3; up). The predicted final particle size distribution is shifted slightly towards smaller particles, compared to experimental measurements (Fig. 3; down). It appears that the rate of agglomeration, which results in formation of larger particles, is most likely slightly under-predicted by the model.

Table 2 - Optimized kinetic parameters of fesoterodine fumarate crystallization

Tablica 2 - Optimirani kinetički parametri kristalizacije fezoterodin fumarata

\begin{tabular}{l|c|c|c|c|c}
\hline $\begin{array}{l}\text { Parameter } \\
\text { Parametar }\end{array}$ & $\begin{array}{c}\text { Nucleation rate } \\
\text { constant } \\
\text { Konstanta brzine } \\
\text { nukleacije } \\
k_{\mathrm{N}} / 1 \mathrm{~m}^{-3} \mathrm{~kg}^{-1} \mathrm{~s}^{-1} \mathrm{l}\end{array}$ & $\begin{array}{c}\text { Nucleation order } \\
\text { Redoslijed } \\
\text { nukleacije } \\
\mathrm{n} /-\end{array}$ & $\begin{array}{c}\text { Crystal growth rate } \\
\text { constant } \\
\text { Konstanta brzine } \\
\text { rasta kristala } \\
k_{\mathrm{G}} / \mathrm{m} \mathrm{s}^{-1}\end{array}$ & $\begin{array}{c}\text { Crystal } \\
\text { Crystal growth } \\
\text { order } \\
\text { Redoslijed rasta } \\
\mathrm{kristala} \\
\mathrm{g} /-\end{array}$ & $\begin{array}{c}\text { agglomeration rate } \\
\text { constant } \\
\text { Konstanta brzine } \\
\text { aglomeracije } \\
\mathrm{kristala} \\
\mathrm{k}_{R} / \mathrm{s} \mathrm{m}^{-7}\end{array}$ \\
\hline $\begin{array}{l}\text { Value } \\
\text { Vrijednost }\end{array}$ & $6.99 \cdot 10^{14}$ & 3.05 & $6.28 \cdot 10^{-8}$ & 1.41 & $6.15 \cdot 10^{9}$ \\
\hline
\end{tabular}




\section{Conclusion}

Mathematical modelling is a useful tool for studying crystallization, both in academic and industrial settings. Batch crystallization of fesoterodine fumarate in 2-butanone under different operating conditions can be adequately simulated after solubility equilibrium and kinetic parameters have been determined experimentally. Further work will be dedicated to more thorough understanding of fesoterodine fumarate crystallization by implementation of other process analytical technologies, such as focused beam reflectance measurement (FBRM).

Model could also be improved by taking into account additional experimental results for more accurate determination of kinetic parameters, such as FBRM chord counts and chord length distributions, as well as crystal size distributions of sampled crystal slurries during the process. In-depth optical microscopy image analysis could help differentiate between agglomerates and primary particles, and thus enable us to determine more accurate crystal agglomeration rate. Additional operating conditions, such as temperature cycling and antisolvent addition, as well as scale-up, will be studied.

\section{ACKNOWLEDGEMENTS}

The authors would like to thank Vesna Stergar and Pavel Drnovšek from Lek d.d. for their support of our research on crystallization modelling.

\section{References \\ Literatura}

1. A. S. Myerson (ur.), Handbook of Industrial Crystallization, $2^{\text {nd }}$ Ed., Butterworth-Heinemann Ltd., 2001.

2. H. H. Tung, E. L. Paul, M. Midler, J. A. McCauley, Crystallization of Organic Compounds: An Industrial Perspective, $1^{\text {st }}$ Ed., John Wiley and Sons Ltd, 2009.

3. A. Mersmann (Ed.), Crystallization Technology Handbook, $2^{\text {nd }}$ Ed., Taylor \& Francis Inc, 2001.

4. U. Ciambecchini, M. Zenoni, S. Turchetta (Chemi S.p.A.), U.S. Patent 8,049,031, 1 Nov 2011.

5. A. Abbas, J. Romagnoli, Multiscale modeling, simulation and validation of batch cooling crystallization, Sep. Purif. Technol. 53 (2007) 153-163,

doi: https://doi.org/10.1016/j.seppur.2006.06.027.

6. P. Marchal, R. David, J. P. Klein, J. Villermaux, Crystallization and precipitation engineering $-I$. An efficient method for solving population balance in crystallization with agglomeration, Chem. Eng. Sci. 43 (1988) 59-67, doi: https://doi.org/10.1016/0009-2509(88)87126-4.

7. R. David, A.-M. Paulaime, F. Espitalier, L. Rouleau, Modelling of multiple-mechanism agglomeration in a crystallization process, Powder Technol. 130 (2003) 338-344, doi: https://doi.org/10.1016/S0032-5910(02)00213-9.

\section{SAŽETAK}

\section{Šaržna kristalizacije aktivne farmaceutske tvari: modeliranje kinetike i ravnoteže Marko Trampuž, a* Dušan Teslićb i Blaž Likozara}

U radu je prikazan razvoj matematičkog modela šaržne kristalizacije fezoterodin fumarata, aktivne farmaceutske tvari, u 2-butanonu. Model se temelji na populacijskoj bilanci te bilanci tvari i energije, a uzima u obzir nukleaciju, rast kristala i aglomeraciju. Ravnotežna topljivost određena je eksperimentalno pomoću spektroskopije ATR-FTIR. Kinetički parametri su određeni primjenom eksperimentalnih i simuliranih krivulja koncentracije i raspodjele veličine čestica za šest kristalizacijskih eksperimenata provedenih pod različitim uvjetima. Model je validiran i rezultati su u skladu s eksperimentalnim podatcima.

\section{Ključne riječ}

Farmaceutski, kristalizacija, modeliranje, kinetike, ravnoteža, fezoterodin fumarat

\footnotetext{
a Department of Catalysis and Chemical Reaction Engineering National Institute of Chemistry Hajdrihova 19, 1001 Ljubljana, Slovenia

${ }^{b}$ Sandoz Development Centre Slovenia, Lek d. d., Kolodvorska 27, 1234 Mengeš, Slovenia
}

Prispjelo 17. travnja 2018. Prihvaćeno 6. lipnja 2018. 